The Evolution of a Capital. A Physiographic Study of the Foundation of Canberra, Australia (Continued)

Author(s): Griffith Taylor

Source: The Geographical Journal, Vol. 43, No. 5 (May, 1914), pp. 536-550

Published by: geographicalj

Stable URL: http://www.jstor.org/stable/1778301

Accessed: 26-06-2016 10:12 UTC

Your use of the JSTOR archive indicates your acceptance of the Terms \& Conditions of Use, available at

http://about.jstor.org/terms

JSTOR is a not-for-profit service that helps scholars, researchers, and students discover, use, and build upon a wide range of content in a trusted digital archive. We use information technology and tools to increase productivity and facilitate new forms of scholarship. For more information about JSTOR, please contact support@jstor.org.

The Royal Geographical Society (with the Institute of British Geographers), Wiley are collaborating with JSTOR to digitize, preserve and extend access to The Geographical Journal 


\title{
THE EVOLUTION OF A CAPITAL. A PHYSIOGRAPHIC STUDY OF THE FOUNDATION OF CANBERRA, AUSTRALIA.*
}

\author{
By GRIFFITH TAYLOR, B.Sc., B.F. (Syd.), B.A. (Cantab.), F.G.S., \\ Acting Commonwealth Geologist.
}

C. Physiography. The Evolution of the Canberra Topography.

(a) Pre-uplift Features.-In an earlier article on the physiography of the Lake George district I have endeavoured to find the age of the fault scarp (Cullarin range), which dammed back the lake, by estimating the amount of silt deposited in the enclosed basin. The method was rough but the result is, perhaps, as near the truth as could be expected with our very incomplete knowledge. The fault is dated at approximately fourteen thousand years ago. Probably this is too recent, and twenty or thirty thousand would be a better estimate.

The country to the east of Lake George consists of broad valleys, with moderately high hills projecting 700 or 800 feet above them. Much the same topography is met with around Canberra, with, however, more alluvial deposited in the form of broader plains. And again, in the Paddy's river area, the topography exhibits the same features, though a narrow gorge excavated in the lower portion of Paddy's river valley shows where some factor (a relative uplift) has led to increased cutting powers of the water. We deduce from this that the last cycle of topography reached a fairly mature stage. It had not quite cut the country down to a new peneplain level, though only the knobs remain at Canberra.

(b) The Canberra Tilt Block.-Now, supposing this "late mature" landscape were effected by earth adjustments in the form of two huge sub-parallel faults (see Fig. 9) in such a way that the block between the faults tilted appreciably, say 300 feet, the western margin sinking and the eastern margin rising by that amount, we should get the structure shown in Fig. 9. The headwaters of the Yass river-if they could not cut down through the fault scarp as quickly as the latter rose-would be cut off and form a lake. Such has happened, and Lake George is the result; while the older watercourse, with large rounded boulders, is to be seen near Geary's gap, perched several hundred feet above the lake. Many other interruptions might be expected. For instance, as the fault scarp lies about 15 miles west of the old Main Divide, it is probable that the headwaters of the Lachlan have also been cut off (Fig. 10). The lakelets of the Breadalbane plains may be relics of the Lachlan system, and so also the curving headwater of the Wollondilly. The latter seems to have captured the upper Lachlan to make up for the huge tributary annexed by the Shoalhaven, which it used to receive from the south. These changes are shown in Figs. 10 and 11.

* Continued from page 395. Map, p. 480. 
On the sinking side of the tilt-block it is natural to find a large river. We should not expect this at Lake George, for here the fault practically coincides with the main watershed. But 40 miles from the Divide a large amount of drainage would be deviated into the new valley, the middle Murrumbidgee, for this would form a rapid "get-away" due north. Not only would streams which formerly ran into the lower Murrumbidgee be deflected somewhat, but also the headwaters of the system to the south might be expected to be influenced. We have seen that this is so from the numerous "boat-hook" bends of the Gudgenby and Murrumbidgee (see Fig. 8). The most gigantic "boat-hook" of all is the whole upper Murrumbidgee, near Cooma (see Fig. 10). If these rivers have changed their course so greatly, other phenomena besides the change of direction ought to be present. The Murrumbidgee fault valley is, from the tributaries' point of view, equivalent to a definite lowering of their "base-level." In other words, it has the same effect as an uplift; so that we get a renewal of cutting force, or a

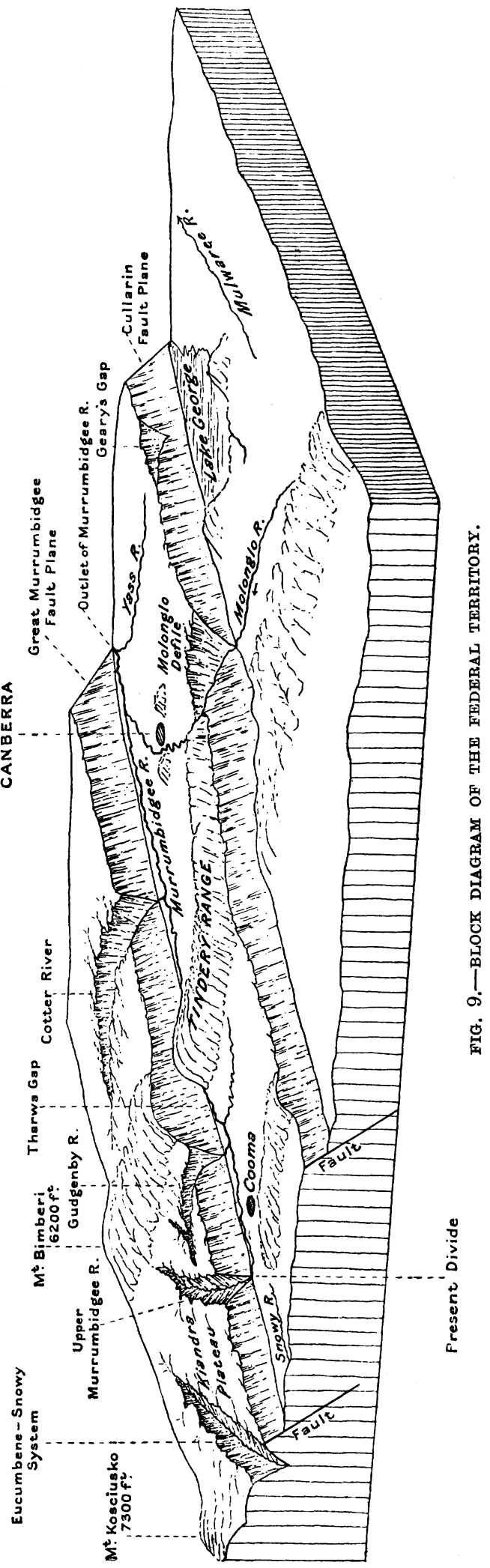




\section{THE EVOLUTION OF A CAPITAL: A PHYSIOGRAPHIC STUDY}

rejuvenation, as it is technically termed. This gives rise to the narrow "young" gorges--several hundred feet deep and not much wider-which mark the lower portions of the Cotter, Gudgenby, etc. (There may also have been uplift, and, in fact, another tilt-block to the west.)

We have seen that the Divide used to lie where the knot of high mountains intrudes on the Murrumbidgee valley, near Tharwa. The

FIG. 10. - SKETCH MAP OF THE PRESENT DRAINAGE OF THE REGION SURROUNDING THE TERRITORY. THE BLACK CIRCLES INDICATE LOCALITIES OF SPECIAL PHYSIOGRAPHIC INTEREST.

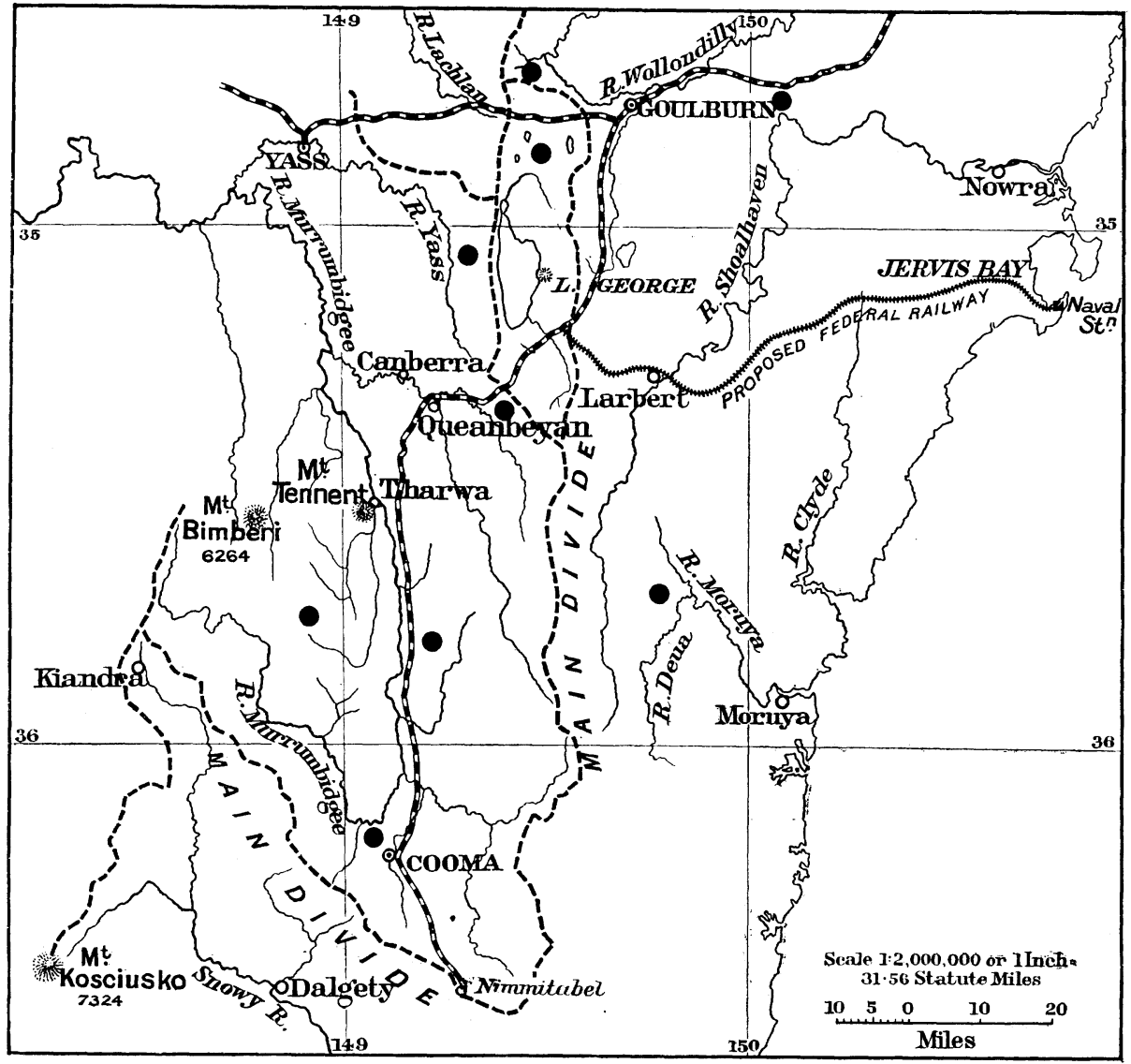

Divide is now 60 miles to the south, between Berridale and Cooma, but the clashing between the two systems-the Murrumbidgee and the ancient Snowy-has resulted in the interesting "cross-fork" contours of Tharwa.

(c) Rivers of South-Eastern Australia.-A word or two on the general river evolution in this south-eastern region of Australia may not be out of place. I have not investigated the very rough country in the extreme west of the territory. The extraordinary valley of the upper Cotter is 
quite possibly another parallel fault plane. Indeed, the Goodradigbee, Tumut, and Adelong rivers, may all have been determined by folding or faulting in accord with the general north-south trend of the rocks in this area (see Figs. 10 and 11). The sudden bend of the Murrumbidgee to the west, near Yass, probably indicates where the river leaves the uneasy

FIG. 11.-THE ANCIENT RIVER SYSTEMS, BEFORE THE PERIOD CF EXTENSIVE FAULTING AND FOLDING WHICH LED TO CAPTURE AND REVERSAL IN MOST OF THE RIVERS, AND MOVED THE COASTLINE CONSIDERABLY TO THE WEST.

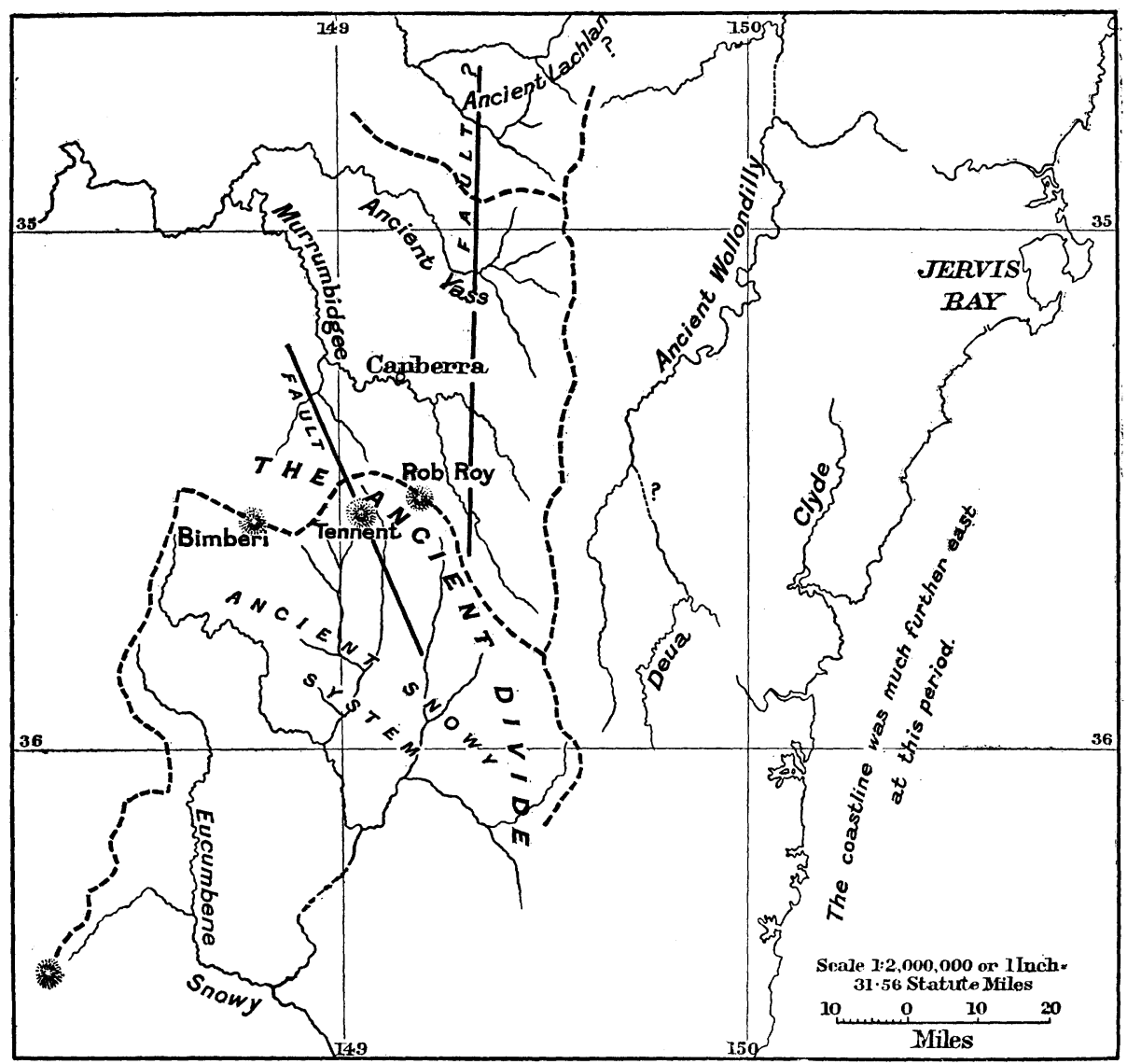

crust of the Monaro highlands for the comparative solidity of the western flanks.

Leaving the Murrumbidgee and Snowy systems, let us look at the coastal streams. Notice the Deua and the Shoalhaven, and, to a less extent, the Wollondilly-Hawkesbury. They flow north along large valleys, and then near the mouth suddenly bend to the east. The Clyde also has this feature reversed (Figs. 10 and 11). Evidently the main drainage is north and south, and the east-west mouths are later features. Even the proposed 


\section{THE EVOLUTION OF A CAPITAL: A PHYSIOGRAPHIC STUDY}

federal port, Jervis bay, is probably a relic of one of these north-south valleys ; but in the case of this one, most of it has vanished before the waves. The two headlands are more or less isolated from the mainland, being joined by rather low and narrow isthmuses.

FIG. 12.-MAP CORRELATING THE CHIEF SEISMIC AREA OF NEW SOUTH WALES WITH THE ANOMALOUS RIVER EVOLUTION OF THE REGION. EACH BLACK DOT (COPIED FROM A MAP BY THE COM(WONWEALTH METEOROLOGIST) REPRESENTS A SEISMIC SHOCK.

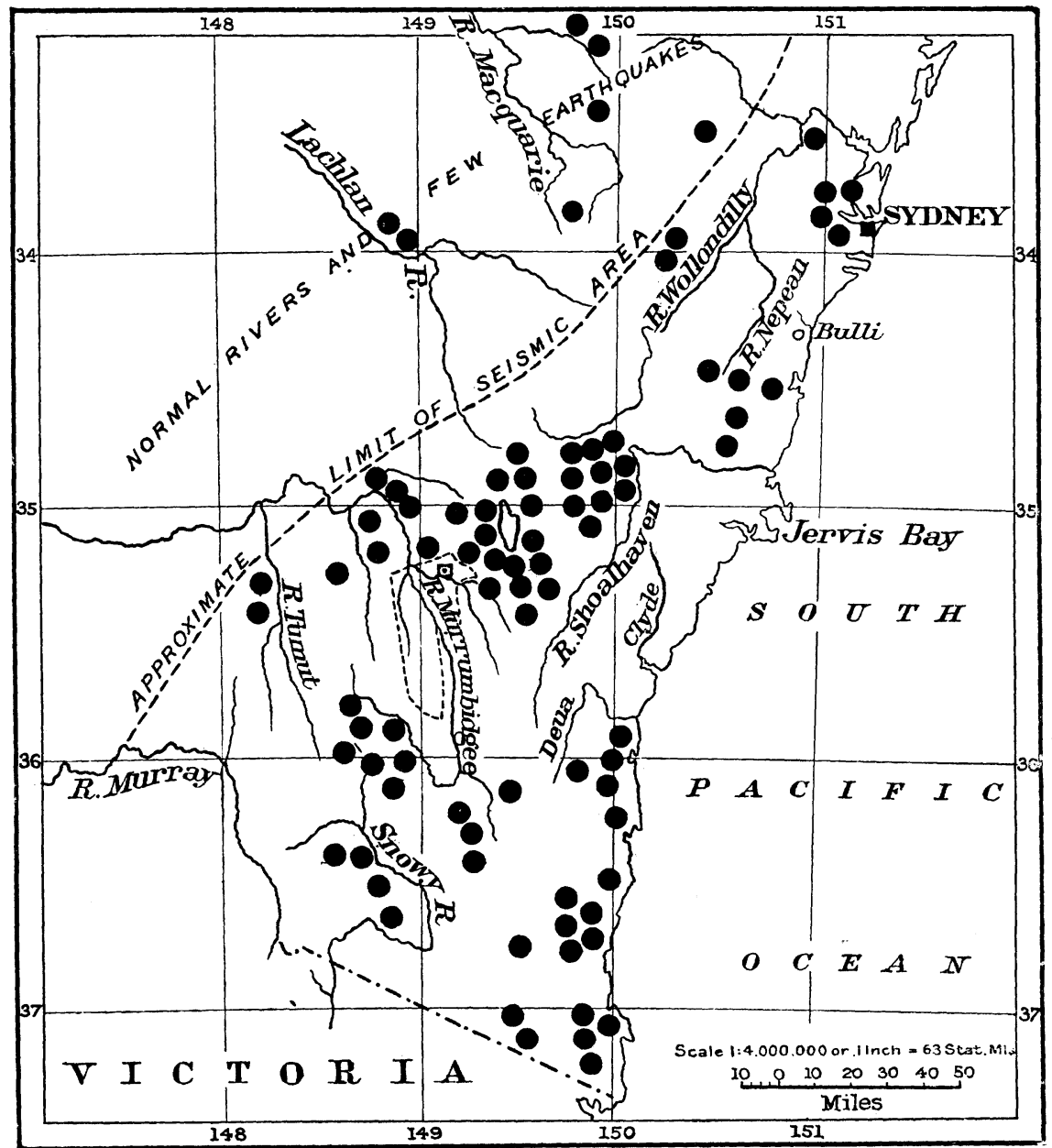

Are there any other phenomena which throw light on this curious distribution of irregular river systems? Why do not the eastern rivers show the normal branching and regular shape of the lower Lachlan and Macquarie-with tributaries uniformly spread over the country so as to carry off the drainage in an orderly and economical manner? See how 
closely the eastern rivers are packed between Lake George and the Murray (Fig. 12). It is as if every subscriber to a telephone system required a separate trunk line. I have elsewhere put forth a "law of physiographic symmetry" whereby I try to show that marked deviation from a uniform and economic system of drainage is to be correlated with striking and comparatively recent tectonic movements. ${ }^{*}$

(d) The Seismic Area.-I think the earthquake map of New South Wales, to which the Commonwealth meteorologist drew my attention in connection with the Canberra faults, undoubtedly helps to explain the anomaly (see Fig. 12). Some vast earth-building (tectonic) forces have robbed New South Wales of a great slice of her coast-line, quite lately in geological time. The change in the main drainage is evidence enough of this. For instance, observe the way the Nepean river (near Cataract dam) rises on the very edge of the 1000-foot sea cliff at Bulli. The other slope of its watershed has vanished beneath the waves (see Fig. 12).

It must not be supposed that these earthquake shocks (shown by black dots on Fig. 12), experienced during the last fifty years or so, are of a very violent nature. They merely mark a re-adjustment of crustal stresses. Probably many small shocks, with quiescent intervals, gradually led to the elevation of the Canberra tilt-block. The fact that the Molonglo could cut through the scarp while it was rising proves this. But the whole of the topography of this corner of New South Wales proves that the history of the area has been a very troubled one in late geological time.

(e) History of the Topographic Cycle.-Possibly the history was somewhat as follows : a continued period of rest led to the production of a peneplain of an advanced type-now represented by the 3000-feet knobs (monadnocks) extending from the Murrumbidgee to Moss Vale. Owing to an uplift of about 800 feet, this peneplain was cut into by the grade of the rivers being steepened, and all the foregoing level country (except the aforesaid monadnocks) was completely eroded. This cycle continued to a stage of late maturity; and at that period the country consisted of broad rolling valleys, whose chief direction was north and north-west. Then, some 20,000 years ago, as deduced from the Lake George infilling, an age of unrest set in. We know of the huge simple fold which constitutes the Blue mountains scarp (above Penrith). We know of the wonderful Nepean gorge (to the north-east of the territory) due also to this movement. The movement extends to Mittagong, and has no doubt influenced the Shoalhaven capture at Tallong (see Fig. 11). To the south the folding has changed into actual breaks in the strata-faults, in fact-and of these we have evidence at Lake George, along the Murrumbidgee, and further south also. Probably at this period huge areas of the coast subsided-it may be as a series of tilt-blocks like the one described in Fig. 9.

Thus the late maturity of the topography has been considerably

* See Bulletin 8, issued in 1911 by the Commonwealth Bureau of Meteorology, Melbourne. 


\section{THE EVOLOTION OF A CAPITAL: A PHYSIOGRAPHIC STODY}

modified, and, owing to the differential character of the movements, the result is that " young" and " mature " features are placed in juxtaposition in a way that makes the path of the investigator difficult, both metaphorically and literally. The edges of maximum uplift are notched by powerful streams, which are technically known as "antecedent," because their courses date from pre-uplift dates. Numerous "obsequent" streams of no great length have scoured gullies down the face of these scarps (e.g. Grove creek). "Rejuvenation" has affected the mature features of the area to a considerable extent, especially near the junction of the tributaries with the main river.

\section{Meteorology.}

The relation between the rainfall and the topography is very well marked in the physiographic area of the upper Murrumbidgee basin. The

MEAN ANNUAL RAINFALL IN REGION AROUND THE FEDERAL TERR:TORY.

From Map by the Commoriwealth Ploteorologlst.

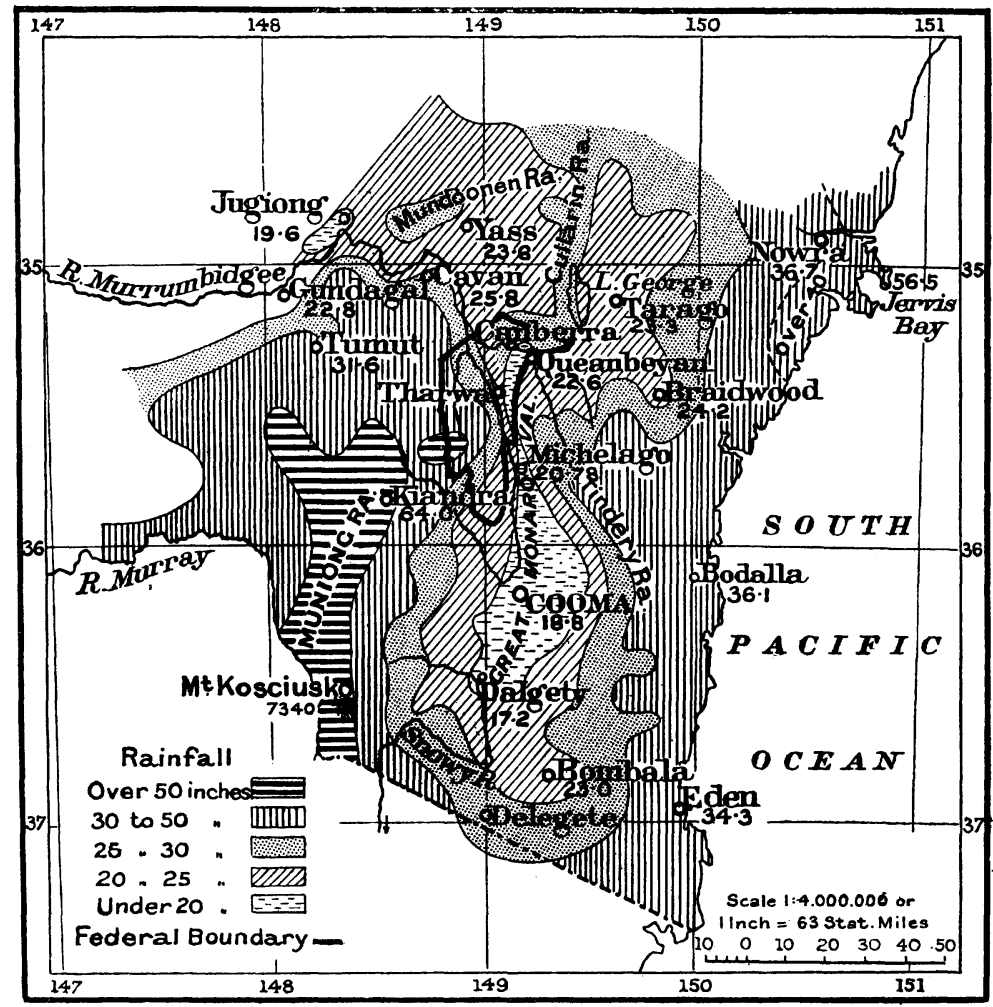

FIG. 13.

rainfall grade is steeper than in any other portion of New South Wales. Within a distance of 40 miles the rainfall has dropped from 64 inches at Kiandra to 19 inches at Cooma (see Fig. 13). But the most interesting 
fact is the elongated arid area extending from Bombala northwards to Queanbeyan, with an annual rainfall of less than 22 inches. This appeared to me to be a result of topography, and led me to realize that there was really a large continuous valley extending for 300 miles, from Cowra southwards over the border and practically to Orbost, on Bass straits. The middle section of this valley I propose to call the Great Monaro valley.

Investigation in the upper Murrumbidgee valley practically confirmed this supposition, though it showed the presence of three bars across the Great Monaro valley, two being of recent date. One of these at Cooma has cut off the upper Murrumbidgee from the Snowy river. Another at Delegate has cut off the Snowy from the Bemm (?) river. The third is the Old Divide at Tharwa, which has been breached by the fault plane and eroded to a comparatively wide gap by the big river. In Fig. 13 the areas over 3000 feet are shown as well as they can be plotted with our rudimentary knowledge of the contours in the Alps. It is seen that this region is broken into three large portions, each with an annual rainfall of over 25 inches. The Mundoonen ranges of 2500 feet (along the north bank of the Yass river) also have a rainfall of about 25 inches. Then the parallel Murrumbidgee-Yass valley forms a drier belt with 21-22 inches. A very interesting isolated arid area is the enclosed basin of Lake George (22-23), separated by a belt of better rainfall (25-27 on the Cullarin fault scarp) from the next area. The lowest rainfall (18-19) occurs in the north of the Great Monaro valley (near Canberra) and in the south of the valley (near Dalgety). On the flanks of the valley the rainfall very rapidly increases to .50 inches on the west and 30 inches on the east.

Naturally enough, the lines in Fig. 13 can only be drawn approximately. Without doubt, when more data are collected, the agreement of rainfall and topography will be found to be more exact in some regions, and not so close as I have shown in others. Moreover, it must be noted that the direction of the prevalent winds is a factor which is independent of the topography, and may very well lead to a want of concordance between the contours and the rainfall.

Meteorological Data.-The average rainfall of the territory is $\mathbf{2 5 . 5}$ inches, or about that of Melbourne or London. The highest recorded average is 32.92 inches at Uriarra, and the lowest $18 \cdot 74$ inches at Duntroon. At Queanbeyan, which is only 8 miles from Canberra, records have been kept for forty-one years. Its elevation and position is much the same, so that the figures for Queanbeyan in the following table must represent those of Canberra very closely.

The mean annual temperature at Queanbeyan is $55^{\circ} \mathrm{F}$., the summer mean being $68^{\circ} \mathrm{F}$. and the winter $42^{\circ} \mathrm{F}$. The prevailing winds during the winter months are from the west. The snow-clad Alps lie to the south-west of the territory, so that some of these winter winds are extremely keen. During the summer hot winds from the west and north-west alternate 


\begin{tabular}{|c|c|c|c|c|c|c|c|c|}
\hline & \multirow[b]{2}{*}{$\begin{array}{c}\text { Elevation. } \\
\text { Feet. }\end{array}$} & \multicolumn{3}{|c|}{ Annual rainfall. } & \multicolumn{4}{|c|}{ Temp. Fahr. } \\
\hline & & Average. & Max. & Min. & $\begin{array}{l}\text { Average } \\
\text { hottest } \\
\text { month. }\end{array}$ & $\begin{array}{l}\text { Average } \\
\text { coldest } \\
\text { month. }\end{array}$ & $\begin{array}{l}\text { Highest } \\
\text { on } \\
\text { record. }\end{array}$ & $\begin{array}{l}\text { Lowest } \\
\text { on } \\
\text { record. }\end{array}$ \\
\hline $\begin{array}{l}\text { Queanbeyan } \\
\text { Brisbane ... } \\
\text { Sydney ... } \\
\text { Melbourne }\end{array}$ & $\begin{array}{r}2000 \\
137 \\
146 \\
115\end{array}$ & $\begin{array}{l}22 \cdot 65 \\
47 \cdot 05 \\
48 \cdot 00 \\
25 \cdot 60\end{array}$ & $\begin{array}{l}41 \cdot 29 \\
88 \cdot 26 \\
82 \cdot 81 \\
36 \cdot 61\end{array}$ & $\begin{array}{l}10 \cdot 45 \\
16 \cdot 17 \\
21 \cdot 48 \\
15 \cdot 61\end{array}$ & $\begin{array}{l}68 \cdot 4 \\
77 \cdot 1 \\
71 \cdot 6 \\
67 \cdot 5\end{array}$ & $\begin{array}{l}39 \cdot 7 \\
580 \\
52 \cdot 3 \\
48 \cdot 5\end{array}$ & $\begin{array}{l}104 \\
108 \cdot 9 \\
108 \cdot 5 \\
111 \cdot 2\end{array}$ & $\begin{array}{l}11 \cdot 1 \\
36 \cdot 1 \\
35 \cdot 9 \\
27 \cdot 0\end{array}$ \\
\hline
\end{tabular}

with cool winds from the south, while frequent north-east winds from the ocean spring up towards evening.

\section{Work accomplished at the Capital.}

(Vide folding map of the territory, p. 480.)

With the exception of the preliminary surveys, work commenced in October, 1909, when the state of New South Wales surrendered the Territory to the Commonwealth. My connection with the capital commenced next year.

In 1907 I made a physiographic survey of the Lake George and Upper Molonglo area, which is structurally a portion of the region occupied by the territory. At this time there was no thought that the capital would be built on the Molonglo and only some 10 miles from Lake George. In July, 1910, I paid my first visit to the actual site, for the purpose of prolonging my study of the physiography to the westward. A keen wind was blowing from the snow-clad Alps to the south, of such intensity that Professor David-who was one of the party-declared it was as searching as any he had recently experienced in the Antarctic! If environment makes for energy, our lawgivers should find the new Houses of Parliament conducive to earnest work, at any rate in winter.

The Federal city of this date consisted of three one-room huts, built of ruberoid fabric, and about a score of tents. The first settlement was in the timber belt just north of Mount Mugga, and was essentially for survey work. A contour survey of the immediate vicinity of the city area was first completed, largely with a view to obtaining a suitable design by a world-wide competition to be referred to later.

Roads throughout the territory were surveyed, and operations thereon commenced. The two main routes to Yass (north) and Queanbeyan (east) were soon improved, so that the traveller could tell from the decrease in the jolting of his conveyance when he entered the territory. Other roads are now in good order. One leads to the Stromlo Observatory (8 miles west) and thence to the Cotter weir just above the junction of the Cotter with the Murrumbidgee. Another goes south to Tharwa and connects with a route up Mount Tidbinbilla (5115 feet), whence a 
grand panorama of the territory can be viewed by the visitor (see Fig. 6). The rugged granite gorges in the south-west at Gudgenby and Orroral have not yet been reached by aught but the roughest bush tracks. Here the settlers find it easier to reach Cooma (over the divide) than Queanbeyan; though the latter seems from the map to be their natural centre of supplies.

By far the most imposing settlement in the territory is the Royal Military College at Duntroon, which is situated on the slopes of Mount Ainslie, about 4 miles east of the city site. This has been in working order for two years, though it was not commenced until November, 1910. Duntroon House-the "homestead" on the former sheep "station"-has been remodelled to make it suitable for an officers' mess. Many large and permanent buildings have been erected for the Officers and Teaching Staff, while laboratories and workshops, stables, barracks, et hoc genus omne, make a sufficiently remarkable show in the midst of a typical Australian "sheep run." The cadets number about 150, and are drawn from New Zealand as well as from the six states.

On Mount Stromlo an observatory has been in operation since 1911; the chief instrument being a Grubb 9-inch refracting telescope presented by Mr. Oddie. The essential conditions for good-seeing prevail in the dry and clear atmosphere of Stromlo. $2519 \cdot 3$ hours of bright sunshine were registered in twelve months of observation during 1911-12. The prevalence of strong winds is an objection, but this would, however, probably apply at any other station 2660 feet above sea-level.

Reference has been made to the railways under construction and survey. Briefly it is proposed to run a complete line from Yass through Canberra to Jervis Bay. Of this the section from Canberra to the existing Cooma line is nearly completed. A geological survey of the actual city site was made in 1910 by Mr. Pittman. During 1912-13 a reconnaissance geological survey of the territory was made by Mr. Mahony and myself, with the results shown in another section. A topographic survey is proceeding, and is about half completed.

The important question of water-supply remains to be dealt with. The city will be built on the banks of the Molonglo river, but this river, although useful for watering stock and (when filtered) for local use, is not large enough to supply a city. Indeed, in midsummer it almost ceases to flow. Yet in a few hours it may change from this condition to a flooded river capable of washing the mail bags out of the coach; an event which actually signalized the end of the dry spell on February 28, 1913. A dam just below the city site will impound this river, forming an artificial lake (4 miles long and about 12 feet deep) which will greatly enhance the beauty of the city.

The city water-supply, however, is to be obtained from the Cotter river, a tributary of the Murrumbidgee river, which flows northward in the south-west portion of the territory. A site for a weir has been selected No, V.-MAY, 1914.] 
about 1 mile above the junction at an elevation of 1560 feet. The weir is being constructed and is about 12 miles W.S.W. of the city; a lift of about 900 feet is required to raise the water to the top of Mount Stromlo, where the distributing reservoir is to be situated. The mean daily flow during 1910-12 was about 50 million gallons, and it is estimated that this is more than sufficient for all the requirements of a city of 200,000 inhabitants. The upper valley of the Cotter is so rugged and far from all settlement that only one or two people have ever traversed it, and the map simply indicates it by a broken line in a perfectly blank strip of territory! Rising in mountains over 6000 feet high, there is no doubt that its head is in a region receiving 60 inches of rainfall a year; while the character of the valley - a gorge 30 miles long without a single tributary-ensures freedom from pollution to a marked degree.

At this stage it will be interesting to inspect the capital on the date (March 12, 1913) when it received its official title of Canberra. Although in cannot be considered far advanced towards its goal yet, it has progressed considerably from the tents of 1910 .

The centre of the official population has moved north across the river to the old homestead of Acton. Here a wooden bridge crosses the Molonglo, and on a low limestone spur to the north the administrative buildings have been placed. They are temporary, of course, built of wood and galvanized iron, as is universally the case in inland Australia. In front is the meteorological compound, the chief feature being a tank to test the evaporation. This is a very important factor in Australia; for it is not much use having even 12 inches of rainfall if the evaporation is 12 feet, as is quite usual in our more arid regions! Across the road is the old homestead of Acton, now the residence of the Director-General of Surveys. Magnificent poplars and willows, elms, and other English trees show that the climate is suitable for British-born residents.

The next few acres are devoted to a nursery for young trees, among which rows of hawthorn are noticeable. I have never seen finer bushes of this tree than those near Canberra, even in England. Eucalypts, Australian pines and wattles are, however, extensively represented in the nursery. The ruthless " ringbarking" of the past century has depleted the country. On the plains, the grass may grow the better, but on the rocky ridges this "improvement" (though stipulated by the conditions of lease) has chiefly resulted in much of the soil being washed off the slopes without any compensating advantage whatever. Another block of wooden buildings form the quarters of the Works Department Officers. To the west, a short distance away under some large eucalypts, is the "canvas town" of the hundred workmen and their families, whose headquarters are here.

A more imposing building, with a large mess-room and comfortable reading-rooms, is the Bachelors' Quarters, for junior draughtsmen and clerks, Behind this again, now among the tree belt, lie the houses of the 
married officers. A small wooden house formed the Administrator's residence, while large military tents furnished the sleeping-quarters of his household; but a permanent residence has just been completed on the highest portion of the ridge for his occupation. Down on the flats, to be submerged by the Molonglo lake, are the cricket field and tennis courts for the staff.

Some 2 miles to the east is Canberra Church and the rectory. As far again is the next community-that of the military establishment of Duntroon. All stores are brought in daily from Queanbeyan-a small town 8 miles to the east. In the whole territory there is only one inn, a somewhat primitive establishment at Hall, close to the northern boundary, so that casual visitors are extremely rare at Canberra.

On March 12, 1913, the capital was officially named Canberra by Lady Denman; the Ministry, in deference to the wishes of the large majority of Australians, having decided to give the name of the parish to the future capital. It is to be noted that the accent is on the first syllable as in most native names, so that the pronunciation closely resembles that of the word "camera."

At intervals of 5 miles or so are the homesteads of the score of sheep stations which are distributed over the territory. Steel windmills, waterholes, and shearing sheds are always in evidence. The district has long been settled, being indeed first occupied about the time of Waterloo, and these old houses are nearly all surrounded by fine trees and often covered with creepers.

At the ford over the Murrumbidgee near the Cotter weir is another " canvas town," with about one hundred men living there. Further to the south, still on the "Big river," is Tharwa, with the granite quarries mentioned in the geological notes. Hall, Tharwa, Jininderra, and perhaps Uriarra in the north-west are the only villages, if such they can be called, within the territory.

\section{Plans for the Future.}

In writing this heading, one involuntarily recalls the tireless energy of the Administrator, Colonel Miller-whose cheery optimism has successfully engineered the city scheme through the most critical portion of its career.

Apart from the city itself, there is an area of some 900 square miles of the territory to be economically developed, which is watered by the second river in Australia. Much of this is undoubtedly suited chiefly to stock, but the large alluvial flats near Canberra itself can certainly be put to more profitable use than sheep grazing-especially with a city arising in their midst to absorb their agricultural produce. Horse-breeding, irrigation, afforestation, are but three of the factors which will vastly enhance the value of the territory in times to come.

It is, however, the actual building of the city which is occupying the 
immediate attention of the authorities. Competitive designs were received from all parts of the world, that of W. B. Griffin of Chicago receiving the first premium. Subsequently the Commonwealth Departmental Board

\section{DEPARTMENTAL}

\section{PLAN OF THE NEW COMMONWEALTH CAPITAL CANBERRA}

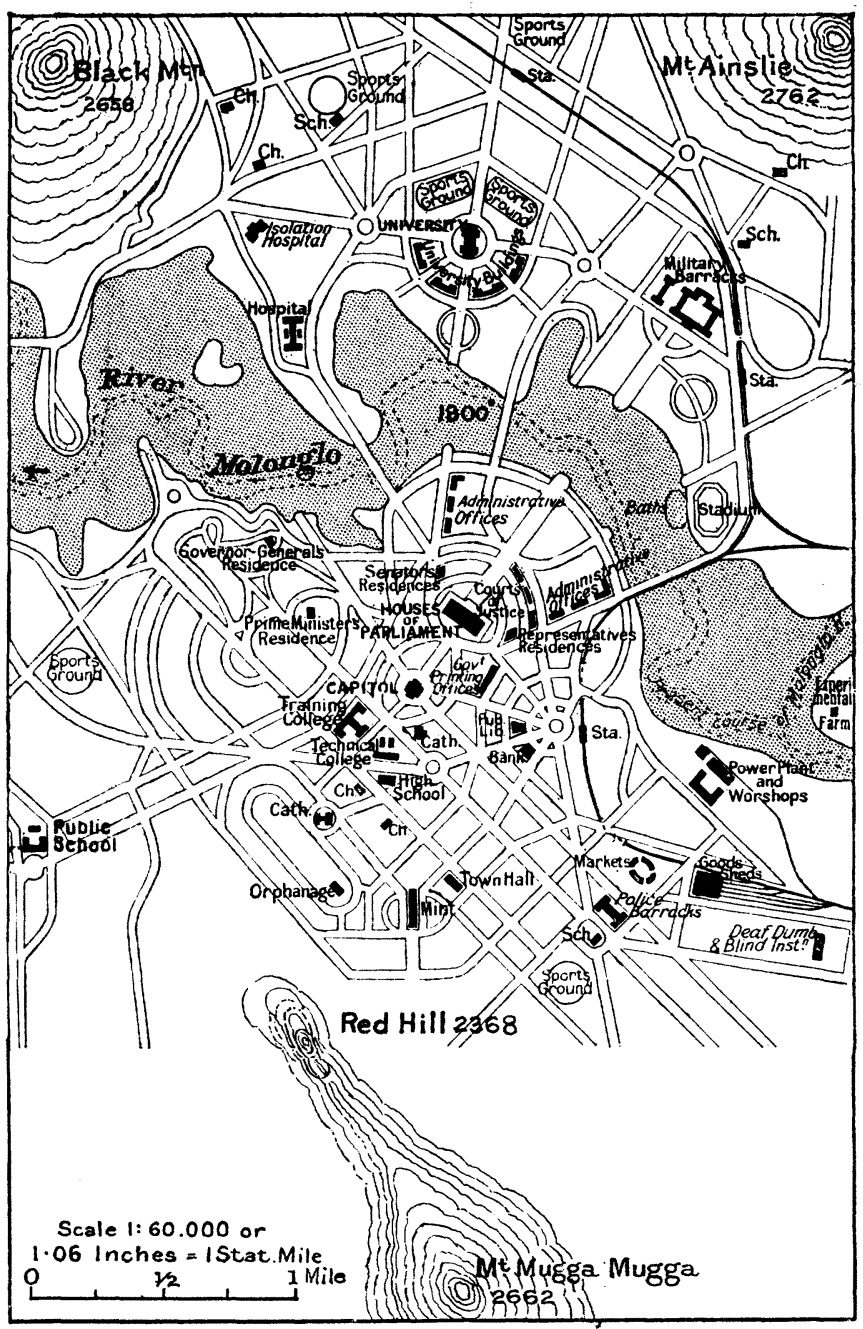

FIG. 14 .

produced a plan which more closely considered the actual contours of the city site. These will form the basis of the actual scheme and a few words on the type of city arrived at will be of general interest. 
The city is to be built on a plain of some 9 square miles, bounded by the abrupt, somewhat conical, ends of three low ranges. These are Black Mountain and Ainslie, on the north-west and north-east respectively, and Mugga on the south. The city will be primarily the official and social centre of Australia. Consequently, the dominating feature of the city will be the Houses of Parliament.

The site of the Houses of Parliament is south of the river Molonglo, on the foothills of Mount Mugga. The administrative buildings will be placed between this spot and the Molonglo. The railway stations will lie to the east of the city, and the line to Yass will curve below the slope of Mount Ainslie to the north. In the east also will ultimately arise the manufacturing centres ; for here, as in most cities, the west end, with its fresh winds, is always the best residential quarter.

In plan it is seen that the rectangular system of streets, beloved of American cities-and also unfortunately used in Melbourne and Adelaideis wisely completely abandoned (see Fig. 14). The cobweb is taken as a pattern, and three of these radiating and concentric units dominate the city plan.

When it is realized that about 90 per cent. of a city's travelling population need to visit the centre of the city every day, the waste of energy in a town such as Melbourne (devoid of radiating streets except in two directions) is enormous.

In the centre of the city will be Lake Molonglo, which will be kept in a pleasing state of purity in a dry summer by the regulating weir higher up its main tributary, the Queanbeyan river. Beautiful panoramas of the city will be viewed from the hills rising sharply 800 feet above the plain on three sides of the site.

We may picture this city of noble granite buildings rising amid boulevards where the sombre beauty of the native trees is relieved by the graceful elms, oaks, and poplars of England. In the centre the lake will be fringed by magnificent willows-as the river is to-day. Some 20 miles to the west the blue crest of Tidbinbilla rises 5000 feet to still bluer skies. In winter it is often covered with a mantle of snow, and in the same range farther to the south stands out the flat top of Long Bimberi-over 6000 feet high and practically the second mountain in Australia.

\section{Conclusion.}

I feel that I cannot more fittingly close this account of the foundation of the capital than by quoting from a speech which I had the pleasure of hearing at Canberra. The ethical aspect of the question is here treated in a masterly fashion. The Governor-General spoke as follows :-

"There are people who say, "Why have a federal capital at all ? Why not let the seat of Government be at Melbourne or Sydney?' The best answer seems to me to lie in the fact that in the judgment of those who framed the Constitution Act of 1900 , federation would have been impossible 
had not a compromise been arrived at in this matter, and would have probably been postponed for at least a generation. Now, the essence of British self-government is compromise, and the acceptance of the accomplished fact.

"Then people say that this federal capital is too costly an undertaking. It is certainly not nearly so costly as it would have been to excise even a few acres for federal territory out of one of the great cities of Australia. But when you consider the great advantages that have accrued from federation-for example, the better relations between States, as evidenced by the abolition of inter-state duties, the building up of an army and navy, the adoption of universal training, and above all the creation of a national Australian spirit-it seems scarcely generous to cavil at the initial expense which must sooner or later be incurred by the founding of this federal city. And I believe that ministers contend, not without force, that owing to the improvement in land values in the federal territory, this is not likely eventually to prove such a costly undertaking. Whether that be so or not, it can scarcely be to the advantage of this country that so large a proportion of people should be massed into great centres of population like Sydney and Melbourne.

"The federal capital cannot hope to vie in wealth and population with Sydney or Melbourne, but that seems to me no reason for discouragement and to afford no ground for regret. The capital of the United States of America is but the sixteenth city in point of population in the union. Yet Washington stands in need of no apology.

"To those who criticize the choice of locality, I would recall this phrase, 'There are no points of the compass on the chart of true patriotism.' The time for doubt, misgiving, and criticism is past; it seems to me the duty of patriotic Australians to do all that lies in their power to make this capital worthy of the Commonwealth."

The data in this paper are derived largely from Government publications, associated in part with the names of Colonel Miller (Administrator), Mr. Scrivener (Director of Lands and Surveys), Mr. Hunt (Commonwealth Meteorologist), and Mr. Knibbs (Commonwealth Statistician). I desire to thank these gentlemen for their assistance, and also Captain Collins and other officers of the Commonwealth Offices in London.

The President (before the paper): Our lecturer this evening, Mr. Griffith Taylor, received his education firstly at Sheffield and afterwards in the Sydney University, Australia, where he graduated in Science and Engineering in 1903-4, and for the three following years was demonstrator and lecturer in geology and geography. From 1907-10 he was at Cambridge University as a science research scholar, and he graduated there in 1909. He became physiographer to the Commonwealth of Australia weather service in 1910, and it was in this capacity that he surveyed the territory set apart as the Federal district of the Australian Commonwealth upon which he is going to lecture to us to-night. Mr. Griffith Taylor has other claims to our admiration and regard. In 1911 and 1912 he 